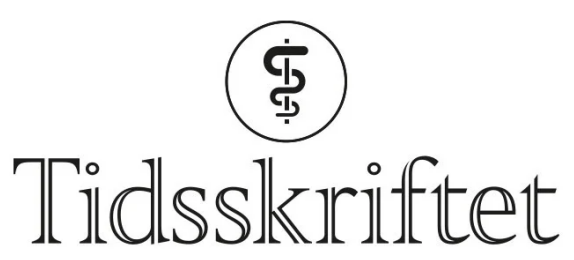

DEN NORSKE LEGEFORENING

\title{
Enkelt og praktisk om allergi og eksem
}

\section{ANMELDELSER}

\section{INGVILD BRUUN MIKALSEN}

Barnelege med kompetanseområdet i allergologi Overlege, Barne- og ungdomsklinikken Stavanger universitetssjukehus

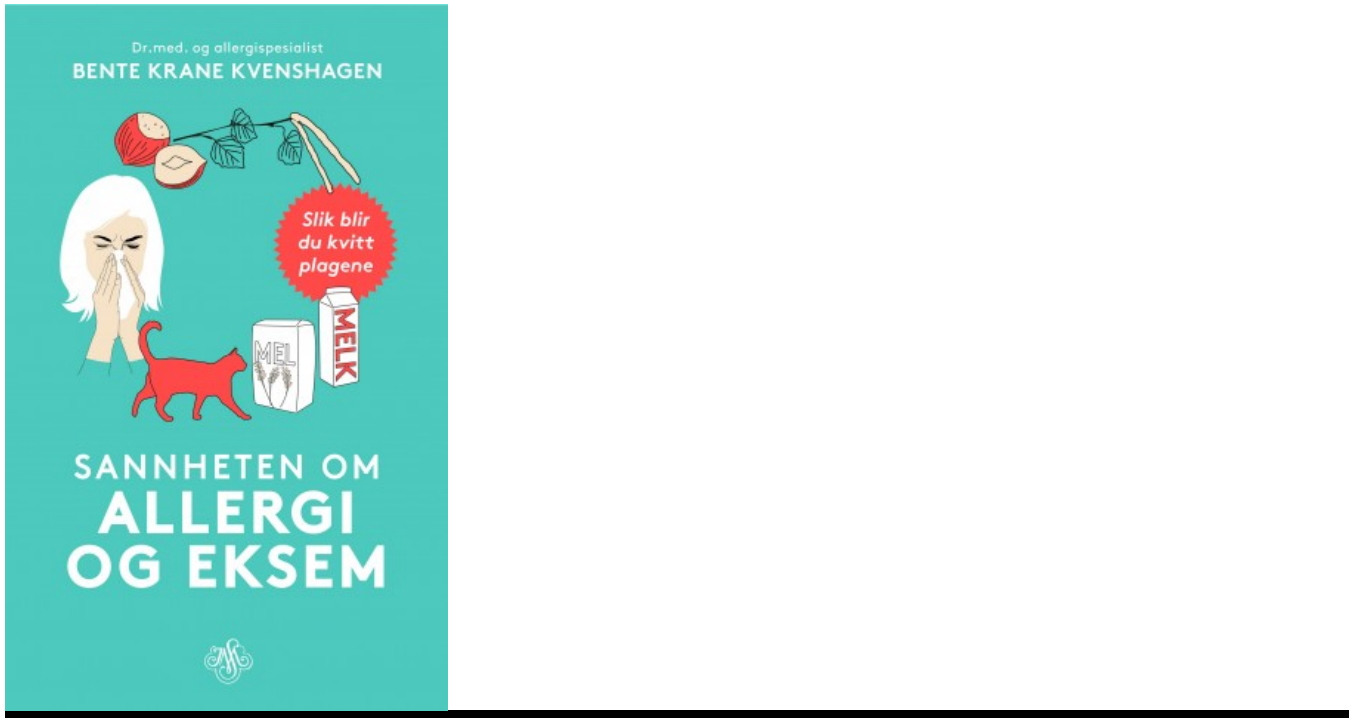

Bente Krane Kvenshagen

Sannheten om allergi og eksem

208 s. Oslo: J.M. Stenersens Forlag, 2020. Pris NOK 379

ISBN 978-82-7201-695-0

Sannheten om allergi og eksem er skrevet av Bente Krane Kvenshagen, barnelege med kompetanse i allergologi. Boken synes mest aktuell for foreldre til barn med allergiske sykdommer og eksem, men også voksne allergikere og helsepersonell med ansvar for denne pasientgruppen kan ha nytte av å lese den. 
Boken består av fire hoveddeler med flere underkapitler. I den første delen skriver forfatteren detaljert om IgE-mediert og cellemediert allergi, men omtaler også tilstander som ikke oppfattes som allergi. Del to omhandler astma med differensialdiagnoser, og del tre symptomer og behandling av atopisk eksem. I del fire beskriver forfatteren hvordan unngå eller bremse utvikling av allergiske sykdommer og oppsummerer med ti hovedpunkter, hvorav daglig oljebad ved tørr hud virker til å være ett av de viktigste.

Forfatteren er engasjert, bruker et folkelig språk, og boken inneholder mange pasientkasuistikker fra egen praksis. Dette gjør boken lett å lese og forstå, også for lesere uten helsefaglig bakgrunn. Forfatterens egne erfaringer kommer til utrykk gjennom hele boken, men hun er nokså nøye med å angi om innholdet er basert på forskning eller egen erfaring. Noen illustrasjoner kunne vært nyttig, spesielt i avsnittene som omtaler mekanismer og patofysiologi. Mekanismer og symptomer ved kryssallergi kunne også vært mer utførlig beskrevet.

Noen av avsnittene i boken blir litt overflødige. Dette gjelder spesielt avsnittene hvor forfatteren deler erfaringer fra egen familie, avsnittet om pencillinallergi og CRP sin diagnostiske verdi for å skille bakterielle og virale infeksjoner, og diskusjonen om oljebad $\varnothing$ delegger vaskemaskinen eller fører til tette avløpsrør. Dette, sammen med forfatterens nokså bastante personlige påstander som at få vet hva irritabel tarm er, mens hun selv hevder å vite mye om det, kan svekke tilliten til boken. I tillegg vektlegges daglig oljebad som et viktig tiltak ved tørr hud eller eksem, på tross av at oljebad ikke ble funnet å ha forebyggende effekt ved eksem i en nylig norsk studie publisert i Lancet (1). Noen resultater fra Lancet-studien omtales, men publikasjonen kunne vært med i referanselisten.

Dette er likevel en bok som pasienter og foreldre kan ha stor nytte av å lese, men leserne bør være bevisste på at boken også inneholder ikke-dokumenterte synspunkter. På tross av begrensningene nevnt over kan også boken være nyttig for helsepersonell.

\section{LITTERATUR}

1. Skjerven HO, Rehbinder EM, Vettukattil R et al. Skin emollient and early complementary feeding to prevent infant atopic dermatitis (PreventADALL): a factorial, multicentre, cluster-randomised trial. Lancet 2020; 395: 951-61. [PubMed]

Publisert: 7. september 2020. Tidsskr Nor Legeforen. DOI:10.4045/tidsskr.20.0493

(C) Tidsskrift for Den norske legeforening 2023. Lastet ned fra tidsskriftet.no 26. april 2023. 